Каламан Ольга Борисівна кандидат економічних наук, доцент, доцент кафедри менеджменту і логістики, Одеська національна академія харчових технологій, вул. Канатна, 112, м. Одеса, 65039, тел.: (048) 725-32-84, e-mail: kalaman.olga@gmail.com, https://orcid.org/0000-0001-5586-7654

\title{
ОСНОВНІ АСПЕКТИ ТАЙМ-МЕНЕДЖМЕНТУ В РОБОТІ КЕРІВНИКІВ ДЕРЖАВНИХ УСТАНОВ
}

Анотація. Стаття показує важливість та значення дослідження таймменеджменту в роботі сучасного службовця. В ній доведена необхідність та значущість виділення пріоритетів як важливого навику сучасної особистості. Показані основні прийоми тай-менеджменту та запропоновані механізми, за допомогою яких доцільно впроваджувати теоретичні знання у практичну повсякденну службу. Підкреслено, що саме працівники державних установ мають особливі проблеми із ефективністю використання робочого часу, який не приносить очевидного прибутку, проте має надважливість для споживачів державних послуг. В статті показано, що для кожного час $є$ невідтворювальним та безцінним ресурсом, про який більшість навіть не замислюється. Зображена роль та вагомість керівника державної установи у роботі всього підрозділу, яким він керує. Зазначено, що застосування технік управління часом потребує певних зусиль і від керівників, і від службовців. Сам процес управління часом охарактеризований як свідомий контроль над кількістю часу, що витрачається на конкретні дії. Підкреслено, що в публічному управлінні час - дуже важливий ресурс; тому керівники повинні планувати і узаконювати час для досягнення поставлених цілей, та порівнювати загальний розрахунковий час для очікуваного завдання. Мета проведеного дослідження сформована як аналізі, порівняння та з'ясування сутності категорії тайм-менеджмент шляхом виявлення його ролі та місця у роботі керівників державних установ. Під час проведеного дослідження зазначена мета була досягнена та представлені висновки, які допоможуть ефективному використанню робочого та особистого часу керівниками та службовцям державних установ. Підсумовано, що ефективне управління часом універсальний засіб підвищення ефективності управління, а не виправдання. Доведено, що ефективне управління часом підвищить продуктивність персоналу, спростить планування робочих місць, змусить службовців виконувати завдання на найвищому рівні кваліфікації, допоможе їм розставити пріоритети і виконати 
важливі завдання, фіксуючи i направляючи організацію до досягнення поставлених цілей.

Ключові слова: тайм-менеджмент, час, управління часом, державна установа, державна служба, керівник.

Kalaman Olga Borysivna Candidate of Economic Sciences, Associate Professor, Associate Professor of the Department of Management and Logistics, Odessa National Academy of Food Technologies, Kanatna St., 112, Odessa, 65039, tel.: (048) 725-3284, e-mail: kalaman.olga@gmail.com, https://orcid.org/0000-0001-5586-7654

\section{MAIN ASPECTS OF TIME MANAGEMENT IN THE WORK OF HEADS OF STATE INSTITUTIONS}

Abstract. The article shows the importance and significance of time management research in the work of a modern employee. It proves the need and importance of prioritization as an important skill of the modern individual. The basic techniques of tiemanagement are shown and the mechanisms by means of which it is expedient to introduce theoretical knowledge into practical daily service are offered. It is emphasized that it is the employees of state institutions who have special problems with the efficient use of working time, which does not bring obvious profits, but is of paramount importance for consumers of public services. The article shows that time is a nonreproducible and invaluable resource for everyone, which most people do not even think about. The role and importance of the head of a state institution in the work of the whole unit, which he manages, is depicted. It is noted that the application of time management techniques requires some effort from both managers and employees. The time management process itself is characterized as conscious control over the amount of time spent on specific actions. It is emphasized that time is a very important resource in public administration; therefore, managers must plan and legalize the time to achieve the goals, and compare the total estimated time for the expected task. The purpose of the study is formed as an analysis, comparison and clarification of the essence of the category of time management by identifying its role and place in the work of heads of government agencies. During the study, this goal was achieved and conclusions were presented that will help the effective use of working and personal time by managers and employees of government agencies. It is concluded that effective time management is a universal means of improving management efficiency, not an excuse. It has been proven that effective time management will increase staff productivity, simplify job planning, force employees to perform tasks at the highest level of qualification, help them set priorities and perform important tasks, fixing and guiding the organization to achieve its goals. 
Keywords: time management, time, time management, state institution, civil service, head.

Постановка проблеми. Час - найважливіший ресурс, який потрібно враховувати при виконанні будь-якої діяльності. Час визначає імперативність будь-яких інших результатів для досягнення поставлених цілей i завдань організації [1]. Це важливий ресурс, необхідний кожному керівнику для досягнення цілей і завдань підрозділу [2]. Водночас, це інтервал між початком $\mathrm{i}$ закінченням операції. Він настільки крихкий, що його не можна зупинити, його можна тільки витратити, проте якщо він неправильно використаний, його вже ніколи не повернути [3]. Час визначають як тривалий або короткий період, протягом якого ви щось робите чи щось відбувається, а управління визначається як дія або вміння успішно справлятися з людьми або ситуаціями. Тому управління часом можна визначити як період, короткий або довгий, який включає в себе те, як люди розумно використовують свій час для досягнення результату. Управління часом починається з прагнення до змін [2].

Аналіз останніх досліджень. Питання ефективного використання існуючого часу турбувало багатьох вчених і сучасності, i дослідників минулих періодів. Серед них можна зазначити основні напрацювання П. Друкера, М. Мескона, Ф. Телора та А. Файоля. Активними прибічниками теорії тайм-менеджменту $є$ Г. Архангельський, Т. Галайда, Н Черненко та інші.

Мета статті. Досліджені автори приділили увагу тайм-менеджменту як науці, проте залишились нероз'ясненими питання щодо його внеску у роботу сучасного керівника державної установи. Саме це і обумовило формування мети проведеного дослідження, яка полягає у аналізі, порівнянні та 3'ясуванні сутності категорії тайм-менеджмент шляхом виявлення його ролі та місця у роботі керівників державних установ.

Виклад основного матеріалу. Важливо зазначити, що кращого управління часом можна досягти, якщо поставити цілі, а потім розставити пріоритети для майбутньої роботи в залежності від того, як вона просуває людину або організацію до досягнення цілей [4]. Цінність управління часом полягає в тому, що у людей надто багато завдань, які їм потрібно виконати, але не вистачає часу на те, що вони хочуть зробити. Управління часом допомагає визначити потреби $\mathrm{i}$ бажання $з$ точки зору їх важливості і зіставити їх з часом і іншими ресурсами. Це також сприяє впорядкованості і дозволяє бути більш продуктивним і повноцінним [2]. Без тайм-менеджменту ефективне і дієве використання всіх ресурсів буде неможливо. Таким чином, тайм-менеджмент виступає як ефективний інструмент, необхідний для організаційної ефективності в реалізації поставлених цілей i завдань [1]. 
Час - нематеріальний ресурс, нееластичний, дефіцитний i нестабільний, i, якщо він вже витрачений, його не можна повернути, зберегти або відкликати для використання [5]. Це важливий безповоротний, обмежений та динамічний ресурс. Безповоротний, тому що кожна витрачена хвилина пішла назавжди, обмежений, тому що у добі існує тільки 24 години, і динамічний, тому що він ніколи не буває статичним [2]. Правильне управління часом призводить до легкого досягнення результатів з обмеженими ресурсами. Отже, будь-яка виробнича система, якою б не була iï структура, кадрова, технологічна або фінансова підтримка, вимагає дієвої та ефективної процедури управління часом. Управляти часом, ймовірно, не так просто, як це представляють і чекають. Отже, дослідники розрізняються за способом визначення управління часом. У своєму дослідженні «Управління часом: ефективність, логіка і виклики» Класенс i Роу відзначили, що термін «управління часом» означає різні речі для різних людей [6].

Управління часом - це організація завдань або подій шляхом спочатку оцінки того, скільки часу буде потрібно для виконання завдання, коли воно повинно бути завершене, а потім коригування подій, які можуть перешкодити його завершенню у відповідній кількості часу. Тайм-менеджмент визначають як ефективне і дієве використання корпоративного часу керівника для досягнення організаційних $\mathrm{i}$ особистих цілей. Він включає в себе визначення завдань, які повинні бути виконані, планування і складання розкладу організаційної діяльності, визначення пріоритетів таких дій, розподіл часу на завдання відповідно до їх ступеня важливості для підвищення продуктивності, мінімізації перерв і рішення рутинних завдань так, щоб важливі завдання могли отримати належну увагу [4].

Управління часом відносять до використання певних технік, таких як списки «справ» або навмисне написання дій, або участь в тренуваннях 3 метою навчання тому, як опанувати таку техніку і використовувати іiі. У загальному сенсі, таймменеджмент визначили як типи поведінки для відрізнення людей, які роблять щось вчасно, дотримуються дедлайну і витрачають трохи часу на свою діяльність, від тих, хто часто спізнюється, сходить 3 дедлайнів, витрачає багато часу на свою діяльність і витрачає час на неважливі справи [6].

Отже, під тайм-менеджментом розуміється свідомий контроль над кількістю часу, що витрачається на конкретні дії. Він також використовується для підвищення продуктивності, ефективності, дієвості, для ефективного планування робочого часу, постановки цілей, розстановки пріоритетів і вибору того, що робити, а що не робити, делегування завдань, аналізу витраченого часу, організації робочого простору, збереження концентрації i зосередженість на роботі, мотивацію працювати над досягненням мети [7]. Управління часом - це не те, щоб зробити більше справ за день. Йдеться про те, щоб робити найважливіше. Час - це властивість природи, яка не дозволяє всім подіям відбуватися одночасно. 
Управління часом відноситься до розробки процесів i iнструментів, що підвищують ефективність і продуктивність [2].

Тайм-менеджмент - це метод для керівників підвищення ефективності роботи [6]. Очевидно, що час є дуже важливим адміністративним інструментом при виконанні повсякденних обов'язків керівників. Л. Маллинс вказує, що «незалежно від характеристик або якостей успішного менеджера або кількості підлеглих співробітників одним з основних критеріїв $є$ ефективне використання часу» [8]. Відповідно, П. Друкер називає час «обмежуючим фактором для ефективних керівників» [9]. В результаті кожному керівнику абсолютно необхідно шукати способи поліпшити управління часом. Будь то керівник державної установи, який прагне поліпшити свій відділ, підрозділ, або окремий службовець, який намагається покращити свій час, управління часом важливо для обох. План управління часом дозволяє ефективному керівнику державної установи визначити, чи ефективно він використовує свій час i виконує важливі дії 3 максимальним рівнем енергії в системі.

У всьому світі поточні зміни на різних рівнях державного управління, пов'язані зі зростанням проблем, очікуваннями, необхідністю працювати i досягати успіху, зробили завдання керівників системи державного управління більш громіздкими і складними. Якщо адміністрація покликана полегшити виконання певних дій i завдань, то те, як службовець планує різні завдання i розподіляє відповідну кількість часу на виконання різних завдань, в значній мірі визначає рівень продуктивності підрозділу [10].

В державному управлінні ці різні завдання і функції включають: реалізацію політики і планування програм; управління кадрами; управління службовим персоналом; технічне обслуговування приміщень; управління закупівлями; управління фінансами; ведення документації. Ці завдання і функції можуть бути продуктивно вирішені керівником підрозділу, якщо він володіє необхідними навичками тайм-менеджменту. Керівники витрачають час кожен день на планування, організацію, контроль, проведення зборів і спілкування. Ці обтяжливі завдання вимагають систематичного підходу до управління часом i чіткого визначення i розподілу обов'язків. Для ефективного управління i контролю необхідно засвоїти навички управління часом [11].

В публічному управлінні час - дуже важливий ресурс; тому керівники повинні планувати і узаконювати час для досягнення поставлених цілей, та порівнювати загальний розрахунковий час для очікуваного завдання [1]. Кожному виду діяльності виділяються певні рамки, в яких діяльність повинна виконуватися в державних установах [12]. Час використовується для обслуговування приміщень, делегування функцій або навіть для витрачання фінансових коштів. Ефективне управління часом забезпечує чіткість цілей, активне планування, чітко 
визначені пріоритети i дії. Плани управління часом, прийняті керівниками, допомагають поліпшити стандарти, скоротити витрати, виправити погані ситуації, підвищити цінність і, перш за все, гармонізувати фокус організації. Він підтримує принцип своєчасного підходу до управління державними процесами для забезпечення якості на різних рівнях. Більшість керівників державних установ приписують неправильне використання часу поганому стилю управління при вирішенні організаційних завдань [1].

Управління часом можливо за допомогою формулювання цілей і визначення практичних шляхів або кроків, які необхідно зробити для їх досягнення. Планування включає в себе адекватний розподіл часу відповідно до видів діяльності, щоб підвищити ефективність ролей i виконання завдань у встановлений період. Планування допомагає уникнути конфлікту між використанням ресурсів через їхню обмеженість. Час має розраховуватися у сфері публічного управління таким чином, щоб можна було легко досягти мети за допомогою доступних обмежених ресурсів. Планування може бути короткостроковим, що охоплює щоденні, щотижневі, щомісячні завдання, або довгостроковим. Призначені графіки роботи та списки справ повинні служити планом того, як можна продуктивно проводити час на роботі. Щоб уникнути невдач, керівник, прагнучи подолати розрив між потенціалом і продуктивністю, має втілити управління часом як вибір способу життя.

Важливо, що час, який у нас $є$, залежить від часу, який ми використовуємо. В результаті, щоб успішно керувати часом, керівники повинні володіти самопізнанням і ставити перед собою цілі. Таке розуміння того, які цілі повинні бути досягнуті, допомагає розставити пріоритети в діяльності. Керівники повинні планувати ефективне використання свого часу і не повинні виконувати завдання випадково. Для цього кожен керівник повинен мати докладну інформацію про його посадові обов'язки [13].

Принцип планування - це правило ефективного тайм-менеджменту 10/90. У ньому говориться, що 10\% часу, витраченого на ретельне планування діяльності заздалегідь, заощадять 90\% зусиль, необхідних для досягнення ваших цілей пізніше. Сам факт того, що керівник державної служби обмірковує і заздалегідь планує свою роботу, різко скорочує кількість часу, яка буде потрібна для виконання фактичної роботи [14].

Організація - це наступний етап після успішного планування. Організація означає залучення всіх ресурсів в план для досягнення цілей. Цей етап управління часом пов'язаний з об'єднанням всіх необхідних ресурсів [1]. Він займається складанням ресурсів для полегшення реалізації поставлених цілей. Організація часу в найпростішому сенсі пов'язана 3 тим, щоб приділяти час роботи у відповідності до людей, місця або потреб. Для досягнення мети керівником 
державної служби повинні бути встановлені терміни.

Тайм-менеджмент дає можливість створювати графіки роботи для досягнення мети і включає розробку і підтримку гнучкого графіка, який залишає можливість включати, що найбільш важливо для певного підрозділу державної служби. Доступні ресурси не тільки обмежені, але i можуть ефективно управлятися, якщо дії правильно організовані, скоординовані і контролюються керівником. Щоб керівники були ефективними організаторами, необхідно дотримуватися наступних принципів організації роботи: розстановка пріоритетів; встановлення тимчасових показників для пріоритетів; залишати час для несподіваного; виділення часу для простою між зустрічами і основною роботою; орієнтація на результат, а не на діяльність.

Коли завдання заплановані, наступним кроком буде розташувати конкретні види діяльності, за допомогою яких очікується досягти цілей, в певну ієрархію, відповідно до їх ступеня важливості для підвищення продуктивності, від найбільш до найменш продуктивних. У зазначеній ієрархії управління часом згрупували численні функції керівника державної служби в три категорії: професійні цільові функції, критичні (кризові) функції і функції обслуговування, при цьому професійні цільові функції знаходяться на вершині, а функції обслуговування - біля основи сходів в порядку пріоритету. Функції професійних цілей включають в себе всі зусилля керівника з розробки і впровадження системи управління i навчання, а також більшість функцій 3 кадрових питань, які безпосередньо ведуть до ефективного викладання i навчання. Функції обслуговування охоплюють всі звичайні управлінські завдання, спрямовані на підтримку стабільності і статус-кво в установі. Критичні функції середнього рівня охоплюють діяльність, критично важливу для управління кадрами, фінансового управління, тощо [15]. Важливо виділяти велику кількість якісного часу відразу на важливі програми замість того, щоб на такі, що розтягнуті на триваліший період. Наприклад, виділяти 2-3 тижні на рік для спостереження і моніторингу. Це дасть керівнику ясну і вичерпну картину, в якому напрямі розвиваються програми діяльності i які загальні i конкретні проблеми існують щодо ефективного виконання запланованих заходів. Однак слід робити поправки на надзвичайні ситуації та несподівані події, оскільки вони неминучі в будь-якій організації [15]. Суть сучасного управління в державних установах межує з відповідальністю i підзвітністю. Найбільша перешкода, яку треба пройти керівникам, - це усвідомити, що вони набагато більш самостійні з точки зору планування дій i забезпечення виконання роботи. Керівники зобов'язані стежити за дотриманням розкладу і відповідності інших співробітників. Наявність певної сформованої мети - це важлива частина системи тайм-менеджменту, проте досягнення іiі - це зовсім інший окремий напрям дій. В кінці певних періодів кожному 
відповідальному керівнику державної установи важливо підводити підсумки фактичних результатів своїх дій і порівнювати їх з встановленими планами. Час не тільки може бути спланований, організований і реалізований, але і оцінений, щоб показати його ефективне використання для досягнення поставлених цілей $\mathrm{i}$ завдань. Це допомагає з'ясувати здійсненність запланованих заходів, чи можуть вони бути виконані у відведений для них час.

Тайм-менеджмент також залежить від принципу ефективності. Це означає зосередження уваги на найбільш важливих питаннях та задачах, оскільки існує думка, що ніколи не буде достатньо часу, щоб зробити все, що потрібно зробити. Те, що має менше значення, повинно залежати від того, що має найбільше значення. Це справжній сенс принципу Парето, який свідчить, що 20\% діяльності становитимуть 80\% цінності вашої діяльності. По суті, це означає, що якщо у вас є список з десяти завдань, які потрібно виконати, два 3 них будуть важити більше, ніж інші вісім разом узятих. Таким чином, ці два види діяльності заслуговують на увагу, оскільки вони вносять найбільший внесок у вашу роботу. Багато дослідників зосередили свою увагу на трьох типах поведінки щодоо оцінки часу, планування і моніторингу [6]. С. Кауфман зазначає, що поведінка при оцінці часу націлена на усвідомлення поточної миті або минулого, усвідомлення використання часу i допомагають прийняти на себе завдання i обов'язки, які відповідають особистим здібностям [17]. Моніторинг поведінки зосереджений на спостереженні як людина використовує час при виконанні дій, створюючи петлю зворотного зв'язку, яка дозволяє обмежити вплив переривань з боку інших [6].

Незважаючи на те, що саме керівники державних установ роблять в конкретний день, їхня зайнятість може частково обгрунтовуватися розширеним плануванням, обов'язками, проте певні чинники грають важливу роль у впливі на методи управління часом керівників. Деякі з них включають:

1) реактивний режим роботи: деяких керівників хвилює тільки, що відбувається в їх підрозділі в даний час. У них немає часу, щоб реагувати на випадкові події, замість цього вони реагують і продовжують скаржитися;

2) нездатність системного осмислення перед діяльністю: вжиття заходів без попереднього правильного мислення $є$ причиною невдач в управлінні часом. Деякі керівники не вірять в принцип ефективного управління часом 10/90 або вважають його важким для застосування на практиці, де йдеться;

3) нездатність придбати нові навички, знання і здібності: деякі керівники не можуть самовдосконалюватися через відвідування семінарів та лекцій, замість цього вони відчувають, що знають все і не потребують оновлення;

4) зволікання 3 важкою складною роботою: деякі керівники переносять відкладання на важку роботу. Замість того, щоб приділити їй потрібний час, вони відмовляються працювати над цими завданнями. Найшкідливішим аспектом 
цього є те, що такі важкі і складні завдання відносяться не до нижніх 80\%, а до верхніх 20\% завдань, які підвищують цінність роботи керівників;

5) інші причини невдач керівників в управлінні часом включають погане командоутворення, відмову розслабитися, слабку творчість, невпевненість, нездатність створити сприятливе робоче середовище, тощо.

Іншими словами, для забезпечення ефективного управління часом на робочому місці керівників державних установ доцільно запропонувати:

1) керівники повинні зосередитися на важливому завданні, щоб підвищити свою продуктивність і заощадити час. Це формує характер керівника і перетворює його в компетентну, впевнену і продуктивну людину;

2) керівники повинні скласти список справ, які потрібно виконати на наступний день. Можна скласти основний список завдань, що містить щоденні, щотижневі і щомісячні списки;

3) хоча пріоритетність завдань залишається найвищою, керівник повинен визначити, в який час доби він $є$ найефективним, і використовувати цей період часу для роботи над найважчими і складними завданнями;

4) перед початком робочого дня керівники повинні налаштувати робоче місце, щоб воно було зручним і сприяло роботі протягом тривалого часу;

5) важливо розвинути почуття невідкладності, оскільки активність і відданість побудові команди і ефективному делегуванню обов'язків;

6) доцільно уникати відкладання на потім;

7) уникати кризового управління: відсутність планування на випадок непередбачених обставин дає час для очікуваного моменту. Приймати помилки, щоб вчитися і уникати наступного разу, та не реагувати гостро;

8) ефективне делегування: не доручати складні завдання, що виходять за рамки навичок персоналу, організовуйте завдання для відповідних людей i 3 потрібними матеріалами.

Висновки. Ефективне управління часом - універсальний засіб підвищення ефективності управління, а не виправдання. Ефективне управління часом підвищить продуктивність персоналу, спростить планування робочих місць, змусить службовців виконувати завдання на найвищому рівні кваліфікації, допоможе їм розставити пріоритети i виконати важливі завдання, фіксуючи i направляючи організацію до досягнення поставлених цілей. Хороша організація щодо використання часу не обов'язково означає постійну якість. Її можна отримати, навчаючись і розвиваючись через послідовну практику і досвід. Час спрацює тільки в тому випадку, якщо людина повністю прив'язана до нього. Для того, щоб створити державну установу, орієнтовану на час, який потрібно буде зробити більш ефективним, ця установа повинна сама раціоналізувати свої процеси. Вигоди, які державна установа отримає в майбутньому, залежать від 
того, що вона робить зі своїм часом зараз. Основним елементом часу є подія, а ключем до ефективного управління часом $\epsilon$ управління подіями. Хоча в реальності ніхто не може науково і повністю управляти ресурсами часу, проте, опановуючи навички управління часом, практикуючи і проявляючи дисципліну, керівники державних установ можуть контролювати свій час для підвищення продуктивності на робочому місці.

\section{Лimepamypa:}

1. Угвулаші К. С. Управління часом та адміністрація школи: проблеми та перспективи / К. С. Угвулаші // Журнал освітніх та соціальних досліджень. - 2011. - № 1 (2). - С. 31-38.

2. Хіршман Е. Теоретичні перспективи використання часу: наслідки для дослідження поведінки споживачів / Е. Хіршман // Дослідження поведінки споживачів. - 1987. - № 2. C. 55-81.

3. Классенс Е. Огляд літератури з управління часом / Е. Классенс // Персональний огляд. 2007. - № 36 (2). - С. 255-276.

4. Ширлі М. М. Інституції та розвиток: досягнення в новому інституційному аналізі / М. М. Ширлі // Челтнем: Едвард Елгар. - 2008. - №10(4). - С. 384-386.

5. Калу Й. Н. Управління часовими ресурсами для ефективного шкільного управління / Й. Н. Калу // Журнал освітніх та соціальних досліджень. - 2012. - № 2 (10). - С. 112-123.

6. Классенс Б. Управління часом: логіка, ефективність та виклики. Час в організаційних дослідженнях: монографія / Б. Классенс, Р. Роу - Лондон: Рутледж, 2009. - С. 23-41.

7. Фібін Дж. К. Котра година / Дж. К. Фібін // Журнал планування менеджменту. - 2012. № 24 (6). - С. 34-41

8. Маллінз Л. Дж. Управлінська та організаційна поведінка: монографія / Л. Дж. Маллінз. - Лондон: Пеарсон Едуцатіон Лімітед. 2005. - 856 с.

9. Друкер П. Ф. Ефективний керівник: монографія / П. Ф. Друкер - Лондон: Вільям Хайнеман, 2007. - 184 с.

10. Калу Я. Н. Управління часовими ресурсами для ефективного шкільного управління / Я. Н. Калу // Журнал освітніх та соціальних досліджень. - 2012. - № 2 (10). - С. 115 -123.

11. Олаволу О.Є. Управління часом в організації освіти: наслідки політики для освітніх менеджерів у штаті Ріверс / О.С. Олаволу, С.Н. Ахайве // Середземноморський журнал соціальних наук. - 2011. - № 2 (4). - С. 63-70.

12. Оджо Л. Б. Ефективне управління часом в організації Панацея чи Плацебо / Л. Б. Оджо, Д. А. Оланіян // Європейський журнал наукових досліджень. - 2008. - № 24 (1). - С.127-133.

13. Каламан О. Б. Роль тайм-менеджменту у формуванні ефективності надання державних послуг / О. Б. Каламан // Інвестиції: практика та досвід. - 2021. - № 3. - С. 75-80.

14. Гісріх Т. Ефективне управління часом для високих показників діяльності в організаціях / Т. Гісріх, Р. Пітерс // Журнал Нігерійського інституту управління. - 2002. - № 44 (3). - С. 21-26.

15. Кілліан Г. М. Підняття сходами до лідерства / Г. М. Кілліан, Дж. Секстон // Бюлетень NASSP. - 1999. - № 63 (425). - C. 9-14.

16. Кауфман К. Ф. Часність в організації: запропонована система якості життя / К. Ф. Кауфман, П. М. Лейн, Дж. Д. Ліндквіст // Бус Псичол. - 1991. - № 6. - С. 79-106.

17. Макан Т. Управління часом: тест моделі процесу / Т. Макан // Журнал прикладної психології. - 1994. - № 79. - С. 381-391. 


\section{References:}

1. Ugwulashi, C. S. (2011). Time Management and School Administration: Problems and Prospects, Journal of Educational and Social Research, 1(2), 31-38 [in English].

2. Hirschman, E. (1987). Theoretical perspectives of time use: Implications for consumer behavior Research. Research in consumer behavior, 2, 55-81 [in English].

3. Claessens, Et. (2007). A review of the time management literature. Personnel review, 36 (2), 255-276 [in English].

4. Shirley, M. M. (2008). Institutions and development: advances in new institutional analysis. Cheltenham: Edward Elgar, 10 (4), 384-386 [in English].

5. Kalu, J. N. (2012). Time Resource Management for Effective School Administration, Journal of Educational and Social Research, 2 (10), 112-123 [in English].

6. Claessens, B., \& Roe, R. (2009). Time management: logic, effectiveness \& challenges. Time in organizational Research, London: Routledge [in English].

7. Fybin, J. C. (2012). What time is it, Journal of Management Planner, 24 (6), 34-41 [in English].

8. Mullins, L. J. (2005). Management and Organizational behaviour. London: Pearson Education Limited [in English].

9. Drucker, P. F. (2007). The Effective Executive, Routledge. London; William Heinemann Ltd. [in English].

10. Kalu, J. N. (2012). Time Resource Management for Effective School Administration. Journal of Educational and Social Research, 2(10), 115-123. [in English].

11. Olawolu, O.E., \& Ahaiwe, C.N. (2011) Managing Time in Education Organization: Policy Implications for Educational Managers in Rivers State, Nigeria, Mediterranean Journal of Social Sciences Vol, 2 (4), 63-70 [in English].

12. Ojo, L. B., \& Olaniyan, D. A (2008). Effective time management in organization Panacea or Placebo. European Journal of Scientific Research, 24 (1), 127-133 [in English].

13. Kalaman, O. (2021). Rol' taym-menedzhmentu u formuvanni efektyvnosti nadannya derzhavnykh posluh [The role of time management in forming the efficiency of government services]. Investytsiyi: praktyka ta dosvid - Investments: practice and experience, 3, 75-80 [in Ukrainian].

14. Gisrich T., \&Peters R. (2002). Effective time management for high performance in organizations, Journal of Nigerian Institute of Management, 44 (3), 21-26 [in English].

15. Killian, G., M., \& Sexton, J. (1999). Climbing the ladder to leadership. NASSP Bulletin, 63, 9-14 [in English].

16. Kaufman, C. F., Lane, P. M. \& Lindquist, J. D. (1991). Time congruity in the organization: A proposed quality-of-life framework. Bus Psychol, 6, 79-106 [in English].

17. Macan, T (1994) Time management: test of a process model. Journal of Applied Psychology, 79, 381-391 [in English]. 